\title{
Global and Local Trends in Development of the Siberian City of Krasnoyarsk
}

\author{
Maria I. Ilbeykina \\ Maria A. Kolesnik \\ Natalia M. Libakova \\ Ekaterina A. Sertakova \\ Alexandra A. Sitnikova \\ Siberian Federal University, Russian Federation \\ Email: Sitnikova_aa@inbox.ru
}

Doi:10.5901/mjss.2015.v6n3s5p241

\begin{abstract}
This article looks at the modern day cultural geography of Krasnoyarsk Krai (Central Siberia, Russia). The article is based on research into the urban image of the Siberian city of Krasnoyarsk and analyzes both its architecture and symbolic representation. Multiple studies suggest that two trends equally affect city development in this day and age: they are globalization and regionalization. By applying semiotic analysis to the city's flagship pieces of architecture and content analysis to local and foreign media covering the city's most prominent and newsworthy events, we were able to establish that Krasnoyarsk's search for self-identity at the turn of the 1990's was most prominently expressed in its visual image and by the early 21 st century was overtaken by globalization trends in architecture; whereas the city's mindset image was shaped overall by two trends: unabated foreign media interest in the area's unique features and local media attention to the day-to-day life typical of any city. The main development resource for Krasnoyarsk is the people living in the city.
\end{abstract}

Keywords: urban studies, Siberian city, Krasnoyarsk, Krasnoyarsk architecture, image of Krasnoyarsk, mass media, social media, content analysis

\section{Introduction}

Nowadays cultural geography goes hand-in-hand with urban studies. Founded in the 1930 s as a specialist field connected with identifying social and economic differences between geographical areas, today cultural geography is a top-ranking branch of science and embraces the broadest range of humanities and social sciences that deal with the idea of cultural and symbolic diversity from a territorial perspective. Humanitarian geography is more than just a scientific approach: it is a way of thinking - thinking unconventionally, that is.

The founders of cultural geography point out that their science has seen a number of changes in recent years (Andersson et al., 2009; Duncan et al., 2004; Lefebvre, 1991; Low, 1996; Mitchell, 2000; Mumford, 1966; Proshansky, 1978). Its range of interests has significantly expanded: it started identifying and explaining cultural transformations occurring in a given geographical area, ranging from the economy and politics of a region or a city to the lifestyles and thoughts of their individual residents. Cultural geography went beyond the established academic boundaries and is now able to study even the issues of gender and sexuality, morality and religion, ethnicity and national origin, wealth and poverty, and more within an urban environment. The results of many studies conducted these days can be found in science magazines specializing in social and cultural geography. These articles are quite distinctive and yet again remind us how broad an outlook this interdisciplinary science has. Special attention is paid to the ideas of space and place: what kind of meaning people assign to them, what kind of feelings and emotions they allow us to experience, how they affect one's everyday life. For example, an article by Bernazzoli (2015) looks into the historical city of Strasbourg: special attention is paid to its modern-day image and the transformation it underwent as a result of growing globalization. Authors of the 2011 book, Beyond Territory: Dynamic Geographies of Knowledge Creation, Diffusion and Innovation (Bathelt et al., 2011), discuss the latest trends in geography, such as a territorial approach to innovation and localized configurations of innovation activity. Both trends are directly linked with globalization and regionalization, the two processes that can be found in each individual area. The research was conducted by an interdisciplinary group consisting of leading experts in 
economic geography, innovative research, political science, and other fields. The purpose of the research was to sum up any up-to-date economic and cultural innovations and new prospects that could lay a foundation for future research into cultural geography. Thus, even looking at a small number of published works on the subject suggests that today's cultural geography can act as a universal platform when studying particular urban spaces. And whatever the researcher chooses to direct their attention to, any process taking place in an area is important in its own way for understanding life as it is today.

A promising branch of today's cultural geography is synthetic analysis of a city as a material and a symbolic phenomenon. An urban space can be analyzed from a material point of view by looking at its architecture, planning, infrastructure, and so on. A symbolic approach to city life may analyze the residents' perception stereotypes of city locations; the ideas that bring the residents together and allow them to identify itself as "citizens" of a particular city in a country; the things that make people feel proud about their place of residence or perhaps complain about having to live in a certain area; and so on.

This article shares the results of a study into the Siberian city of Krasnoyarsk as viewed from these two perspectives. It is important to mention that out of the many possible approaches to analyzing a city culture, we chose to try and analyze Krasnoyarsk's architecture and media content in order to identify the symbolic meanings that are attached to Krasnoyarsk and reflected in its residents' mindset. That is, the article offers only the tip of the iceberg rather than all the material and symbolic information about Krasnoyarsk that could otherwise be presented.

We turned to a combination of global and regional trends within a city culture as the fundamental development trend for Siberian cities (and used Krasnoyarsk as an example), and this determined our choice of content for the analysis.

\section{Literature Overview}

The terms "globalization" and "regionalization" are fairly popular with Western and Russian social sciences alike, but their understanding of the terms often differs. Russian researchers view globalization as a powerful influence coming from a foreign culture and replacing community-specific traditional views on the world, the society, and the man with a set of standardized views (Inozemtsev, 2002; Nistarova, 2013; Proskurin, 2000, etc.). Regionalization is viewed as an opposing process. Unfolding side-by-side, these processes are non-linear and different in scale. Non-Russian scientists, including those who were the first to discuss the issue (see Florida, 2008; Fukuyama, 1993; Gray, 1992; Huntington, 1996; King, 1999; Sztompka, 1993), believe that these are complex and many-sided phenomena that are dialectically interconnected and interdependent and have a large number of positive aspects.

Today's research on how globalization and regionalization manifest itself in urban environments (Agnew et al., 2004; Bordo, 2003; Castells, 1983; 1992; 2002; Gospodini, 2004; Graham, 2000; Grant \& Nijman, 2002; Jameson, 1991; Judd \& Simpson, 2008; Kearney, 1995; Knox \& Pinch, 2009; Sassen, 1991; 2012; Westwood; 2005, Zukin, 1996) deal with the theoretical and methodological issues of globalization and regionalization and study the role that megalopolises play in the modern world and the way they affect international life. Some scholars (Allen, 2000; Casey, 2001; Davis, 1998; Harvey, 1973; 1989; Kaymaz, 2013; Smith \& Bugni, 2006; Smith et al., 2002; Soja, 1989; Wu, 2000) stick to the opinion that all globalization and regionalization-related changes, whether economic, political, cultural or social, can be uncovered by looking at urban architectural forms or studying people's views on a city's image or status.

These days we are seeing an increase in the number of published studies on Russian cities and their spatial and territorial relationship with the modern world (Petrov, 2012). The urbanization of Central Siberia which is home to indigenous peoples of the Siberian Arctic comes with a need to balance modernization and preservation of the unique indigenous culture (Karlova et al., 2013; Kistova et al., 2014; Koptseva \& Kirko, 2014a; 2014b; Libakova et al., 2014). Studies of Siberian cities in general and Krasnoyarsk as a large Russian city in particular (Ilbeykina, 2011; Kolesnik \& Mirkes, 2011; Koptseva et al., 2011; Koptseva et al, 2015; Pimenova, 2011; Semenova \& Soshenko, 2011; Sertakova, 2014) suggest that Krasnoyarsk, one of the biggest and most promising Central Russian cities, is also subject to modernization and regionalization. Our research shows that modern city development (Krasnoyarsk in this case) depends on both internal patterns (regionalization) and external factors (globalization).

\section{Research Methodology}

This research is a first step in looking at a city (Krasnoyarsk in this case) from two interconnected perspectives: as a piece of territory and as a mental construct. The two main methodological approaches used in the research are: 1) semiotic analysis of the city's architecture and 2) media content analysis. 
For studying the city as a physical piece of territory, semiotic analysis was used when studying some of Krasnoyarsk's architecture, namely the Krasnoyarsk Museum Center and a local business center, Pervaya Bashnya ("First Tower").

Media content analysis was applied to study Krasnoyarsk as a mental construct. Since the focus of our research was coexistence of global and regional trends in city development, we turned to foreign and local media and social networks to analyze their content and compare how Krasnoyarsk is perceived by the international community and by the people living in the city. Content analysis was used when studying Krasnoyarsk's image in foreign media to get a basic idea of which Krasnoyarsk events tend to become internationally newsworthy. Content analysis was also used to study local social media and identify which events caught the residents' attention.

Rather research into Krasnoyarsk's image at the international level was conducted by content-analyzing the news about the city coming from the Reuters International News Agency. This particular agency was chosen due to many foreign media turning to it for information when creating their content. Also, there is a Reuters correspondent living and working in Krasnoyarsk who regularly reviews the local news. Of course, publications on Krasnoyarsk can be found in other reputable international media, such as The New Yorker, The New York Times, and The Sun, but they tend to cover Krasnoyarsk from a slightly different perspective (a city on the Trans-Siberian Railway which European hipsters enjoy traveling so much; Krasnoyarsk-based M. Godenko dance company doing a series of shows with the opera singer D. Hvorostovsky; Vissarion; and so on), whereas we were looking to keep our data consistent and hence went for Reuters news alone.

To get an idea of the Krasnoyarsk symbolic field created by people living in the city, we turned to the subjects discussed in online communities based in the social network, VKontakte: I Live in Krasnoyarsk (a public page, 191,923 followers), I Will Die in Krasnoyarsk (a public page, 3,200 followers), Our Krasnoyarsk (a public page, 59,154 followers), Prospekt Mira (a media page, 41,759 followers). These particular communities were chosen for the study because they have the biggest number of followers.

\section{Findings and Discussion}

Presented first are the results of our analysis of the global and regional trends in Krasnoyarsk architecture, that is, in the city's material structure. Krasnoyarsk architecture of the early $21^{\text {st }}$ century shows a clear trend towards globalization, which reveals itself in the buildings dominating Krasnoyarsk's construction industry these days, such as shopping malls, business centers, and new housing developments. In order to get a clearer picture of how global trends are expressed in Krasnoyarsk architecture and what kind of local touch they have, let us take a look at the Pervaya Bashnya business center.

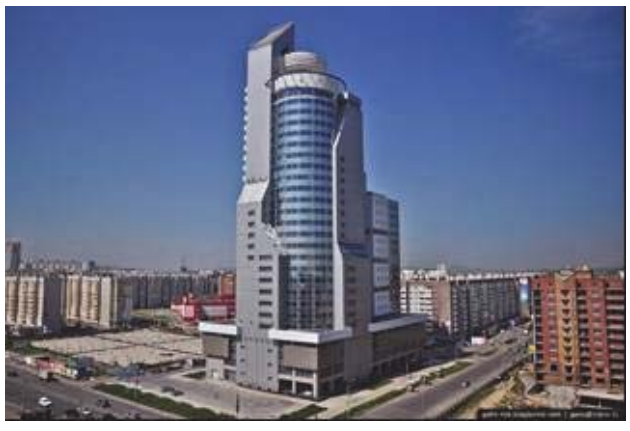

Figure 1. Pervaya Bashnya ("First Tower"), a business and shopping center

Built in 2009, Pervaya Bashnya (designed by architects A. N. Dobrolyubov, S. N. Dobrolyubov, and P. A. Zhabin), is a good example of modern-day Krasnoyarsk architecture. The tower is a high-rise building clearly dominating the city's architectural landscape.

One can hardly call this a one-piece compact building; it is rather a collection of separate architectural pieces varying in height: a massive rectangular base housing a three-level shopping mall; a tube-shaped tower featuring a lighter construction thanks to extensive use of glass; and a rectangular extension which is also more of a set of building blocks featuring equal amounts of glass and veneer. The building is topped with a round-shaped helipad and an adjoining arrow- 
shaped tower. As of today, Pervaya Bashnya is the tallest building in Trans-Urals Russia. Its name which translates as "First Tower" hints at the project's ambition to dominate the cityscape and define its future transformation.

The building in question is unusual for Krasnoyarsk and immediately captures attention. Its construction is nonsymmetrical. The rectangular base suggests that the shopping mall acts as a stability symbol for the entire building. The foundation in this case is the economic activity aimed at buying and selling goods. The medium part of the building and the tube-shaped tower that provides offices to the most sophisticated of tenants symbolize progress and profit growth. The building's overall outline also supports this idea. Pervaya Bashnya's asymmetrical silhouette looks like a towering victory podium or an upward-trending profit graph.

The tower itself is reminiscent of big US city architecture. This is another reason why it became such a prominent landmark: it is a modern building designed with global architectural trends in mind. This kind of architecture has been around all over the globe for quite a while: these buildings are simple in shape, but catch the eye with their large glass panels reflecting the space around them. Mirror-like glass panels covering these buildings not only demonstrate the knowledge of global architectural trends, but also showcase highly developed technologies. Pervaya Bashnya visually incorporates Krasnoyarsk's economic development and growth, acts as a landmark for residents and as a symbol representing the entire city and its region, for visitors. This business and shopping center is an emblem of fast-paced development and breakthrough.

Looking at the ideas it carries, one can say that this massive core-shaped skyscraper represents a breakthrough in man's abilities. With mountainous landscapes and plenty of "dictator"-style buildings around, Pervaya Bashnya is a sign of the "enthusiast"-style approach in action, an attempt to give the city a more up-to-date look up to the Western standard. This is more of a step towards the typical, a desire to turn Krasnoyarsk into a world-class city at the forefront of business and collaboration.

Our search for clearly defined local trends in Krasnoyarsk architecture cannot focus on modern buildings alone since manufactured standard housing developments and shopping malls (with a trend towards all-glass facades, taller buildings, and bright colors tacked on to design solutions) does not suggest that due attention is being paid to promoting the authentic local tradition. For this reason, let us turn to a prominent example of local Krasnoyarsk architecture: the Krasnoyarsk Museum Center built in 1987 by A. S. Demirkhanov.

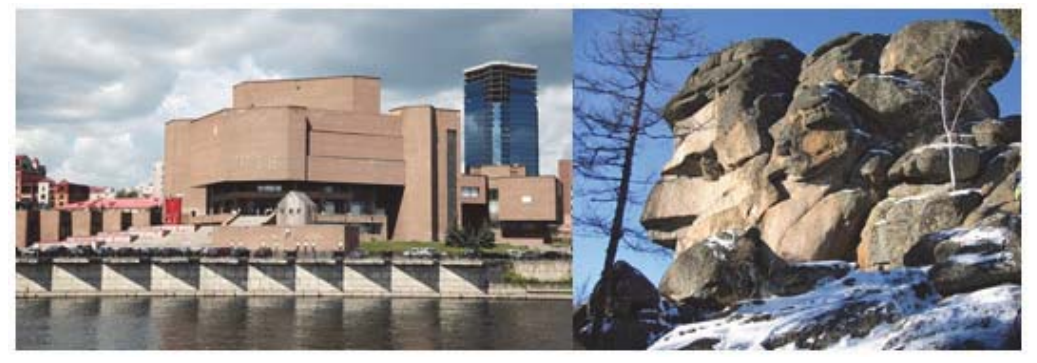

Figure 2. Exterior of the Krasnoyarsk Museum Center and the Ded ("Grandfather") rock at the Stolby Nature Reserve

The building is sitting on Krasnoyarsk's historical founding site in the Strelka ("Arrow") area where the city's main river, the Yenisei, meets a rivulet called the Kacha. The building is a set of two massive parts: viewed from above, one is octagonal-shaped and the other is a square; there is a gallery joining them at the second floor level. On the riverside, which is where the main entrance is, the building is surrounded with cascades of stairs and pools for what originally was meant to be a row of fountains. The facade is decorated with monochrome granite plates giving it a rock-like appearance. Switching to local trends in this piece of architecture, we would like to point out that the building was inspired by the rocks of the Stolby Nature Reserve which is the city's key attraction. According to the architect himself, the inspiration came specifically from the Ded ("Grandfather") rock. The idea of keeping architectural solutions in tune with the local nature continues to be found in just about everything: the windows on the inside are designed to look like picture frames through which one can enjoy the natural views; a cascade of fountains is supposed to run down into the river linking the museum with the Yenisei (the project is still under construction); a long stained-glass panel in the gallery matches the river flow rhythm; and the building itself is a bit like a labyrinth where exits and entrances cannot be easily identified and interior space arrangement may not strike one as logical, which only brings it closer to the irrational ways of shape-creating in the nature. 
As a result, one can say that the key regional trend in Krasnoyarsk architecture (other than traditionally Siberian ornaments and other design elements found in the authentic Siberian wooden architecture) is drawing inspiration from the unique shapes of Siberian nature and using local building materials (granite facade plates, for example, clearly replicate the texture of Krasnoyarsk rocks with their complex shapes). The Krasnoyarsk Museum Center is currently due for renovation: the plan is to replace the granite cladding with multicolored suspended luminous facades, which is yet another manifestation of globalization aspirations in Krasnoyarsk architecture of the early $21^{\text {st }}$ century.

As announced above, other than looking at the city culture from the material perspective, we also would like to share the results of our research into the symbolic meanings attached to the city of Krasnoyarsk either by the international community or by the city's residents itself.

For content analysis purposes we studied the information on Krasnoyarsk that appeared in Reuters from 2010 to 2015 inclusive. Krasnoyarsk was mentioned 58 times in total. We were able to identify the following subject areas connected with the city of Krasnoyarsk: 1) news on big corporations operating in Krasnoyarsk Krai, such as RUSAL, Norilsk Nickel, Polyus Gold, Vankorneft, a number of Chinese and Japanese corporations trying to set up their factories in the area, and others; statements and actions by heads of these corporations also regularly appear in the media (this, in fact, was the hands-down leading type of Reuters news on Krasnoyarsk); 2) analysis on the area's economic and resource development (analytical data regarding the prospects of oil, gold, and other mineral resource extraction in the area is a common subject in the news agency's content); 3) sports and, first of all, Olympic champions with Krasnoyarsk background: the years 2010 and 2014 saw an increase in sports news thanks to the Olympics, and Krasnoyarsk was mentioned as some champions' hometown; 4) there is still a high concentration of prisons in the Krasnoyarsk area, which is why news on Krasnoyarsk prisons regularly appear in the media (in the recent years this was thanks to Nadezhda Tolokonnikova and Valentin Danilov being freed from Krasnoyarsk-based prisons; another area of interest was comparing today's Siberian prisons with the Soviet Gulag); 5) finally, a small percentage of content dealt with the curiosities of Krasnoyarsk life, such as a female blacksmith; an artist who created a pearl-clad picture for the UK Queen; a doctor who stole a bag of heroin from a patient's stomach; and others.

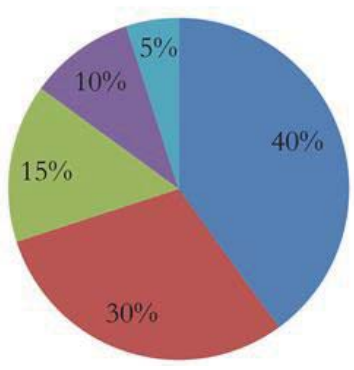

News on big corporations
operating in the Krasnoyarsk
area
Economic and resource analysis
of the area
Sports (Krasnoyarsk-born
Olympic champions)
Krasnoyarsk prisons

Figure 3. Krasnoyarsk in foreign media

Source: based on the results of content analyzing of Reuters news on Krasnoyarsk

As we can see, the international news agency suggests that Krasnoyarsk has the following symbolic field around it: Krasnoyarsk is a big Siberian city situated in an area rich in natural resources; a hometown for some Olympic champions; a place of exile for Russian non-conformist intellectuals; and a place featuring some weird modern-day behavioral patterns. As for the way Krasnoyarsk residents view their city from the symbolic perspective, our study of the top social media discussions yielded the following results.

Content analysis allowed us to identify the following range of subjects discussed on these pages starting the year 2015: education, culture, society, politics, accidents, city improvements, sports, animals, nature and environment, economy, extremism, religion, housing and utilities, food inspection, industry, medicine, science, human interest stories, quotes about the city and its residents, local humor, humor (reposted from other communities), weather, and dating.

On the whole, this is a typical selection of subjects that can be found in any other city's community; the way Krasnoyarsk people view itself and their city can be judged by how much discussion each of these subjects generates. For example, accidents, such as fires, road accidents, crime, and others, made up the most discussed category. The runner-up was humor with a variety of subjects. Equally discussed were society (common events occurring in people's everyday lives) and quotes about the city (short and often ironic image captions expressing what it is like to live in 
Krasnoyarsk: beautiful nature, severe weather, traffic jams, awkward public transport, shortage of nursery places, and so on).

From the residents' point of view, the symbolic field around Krasnoyarsk appears to be the following: Krasnoyarsk is home to dynamic people blessed with an excellent sense of humor who find itself in various accidents, enjoy dating, discuss social issues, and have a keen interest in the economy, politics, sports, cultural events, education, and science, but would rather turn their attention to nature and animals.

\section{Concluding Remarks}

Once we analyzed Krasnoyarsk topography by looking at some of its architecture, we were able to identify a clear globalization trend present in the city. Regional trends are no longer welcome in the city planning projects (which can be seen from attempts to give the city's cultural and historical center a makeover by introducing suspended luminous facades and from an inclination to construct modern-looking skyscrapers). The exterior design of the buildings we analyzed suggests a tendency towards a more typical look all over the modern city area, with diluted unique historical and cultural features that used to be still part of the city's landscape in the late 20th century. With this kind of look, the city carries a message that it is a big economic and business center keeping up-to-date with global trends.

Our analysis of the symbolic component, that is, the way Krasnoyarsk is perceived by the international community, suggests that this Siberian city is seen first and foremost as a repository of natural resources attracting multinational corporations. Their presence in the area is well in tune with the globalization trends in the city's material structure. At the same time, local people's perception of the city indicates that there is a prominent regional component too. Residents view their city through a prism of unique events and phenomena typical of this area only. They associate Krasnoyarsk with rich natural resources, one-of-a-kind Siberian landscapes, and local character traits (grim, but not unlikeable people with their unique views).

As we can see, there is a clear clash of trends: the city's "body" is busy adjusting itself to fit in with the modern world, whereas the "mind" is still thinking its regional thoughts.

\section{References}

Agnew, J.A., Mercer, J., \& Sopfer, D.E. (1984). The city in cultural context. Boston, London, Sydney: Allen and Unwin inc. Allen, J. S. (2000). The Cultural Economy of Cities: Essays on the Geography of Image-Producing. London.

Andersson, K., Domosh, M., Pile, S., \& Thrift, N. (2009). Handbook of Cultural Geography. Sage Press.

Bathelt, H., Feldman, M., \& Kogler, D.F. (2011). Beyond Territory Dynamic Geographies of Knowledge: Creation, Diffusion and Innovation. Routledge.

Bernazzoli, R. (2015). Cosmopolitan Europe: a Strasbourg self-portrait. Journal of Social and Cultural geography, 16(1), 118-120.

Bordo, M.D., Taylor, A.M., \& Williamson, J.G. (2003). Globalization in Historical Perspective. Chicago.

Casey, E.S. (2001). Between Geography and Philosophy: What Does It Mean to Be in the Place-World? Annals of the Association of American Geographers, 91(4), 683-693.

Castells, M. (1983). Crisis, planning, and the quality of life: Managing the new historical relationships between space and society. Environment a planning. D. Soc. a. space, 1(1), 3-21.

Castells, M. (1991). The Informational City. Information Technology, Economic Restructuring and the Urban-Regional Process. Oxford, Cambridge: Blackwell.

Castells, M. (2002). Local and Global: Cities in the Network Society. Journal of Economic and Social Geography, 93(5), 548-558.

Davis, M. (1998). Ecology of fear: Los Angeles and the imagination of disaster. New York.

Duncan, J.S., Johnson, N.Ch., \& Schein, R.H. (2004). A companion to cultural geography. Oxford: Blackwell Publishing.

Florida, R. (2008). Who's your city? Basic Books.

Fukuyama, F. (1993). The End of History and the Last Man. New York.

Gospodini, A. (2004). Urban morphology and place identity in European cities: built heritage and innovative design. Journal of Urban Design, 9 (2), 225-248.

Graham, S. (2000). Constructing premium network spaces: reflections on infrastructure networks and contemporary urban development. International Journal of Urban and Regional Research, 24(1), 183-200.

Grant, R., \& Nijman, J. (2002). Globalization and the Corporate Geography of Cities in the Less-Developed World. Annals of the Association of American Geographers, 92(2), 320-340.

Gray, C. (1992). The geopolitics of Superpower. Kentucky.

Harvey, D. (1973). Social Justice and the City. Baltimore: John Gopkins university press.

Harvey, D. (1989). The urban experience. Oxford: Basil Blackwell.

Huntington, S.P. (1996). The Clash of Civilizations and the Remaking of World Order. New York: Simon \& Schuster.

Ilbeykina, M. (2011). Civilizational Orientation of the Population of the United Krasnoyarsk Krai: 15 to 60 Years of Age Residents of 
Krasnoyarsk City. Journal of Siberian Federal University. Humanities \& Social Sciences, 6 (4), 846-864.

Inozemtsev, V.L. (2002). Na pereputje: Rossia v mirovoj sisteme XXI veka. Obschestvennye nauki i sovremennost', 4, 101-112. [in Russian]

Jameson, F. (1991). Postmodernism, or, the Cultural Logic of Late Capitalism. Durham: Duke University Press.

Judd, D.R., \& Simpson, D. (2011). The city, revisited urban theory from Chicago, Los Angeles, and New York. London.

Karlova, O., Koptseva, N., Kirko, V., Reznikova, K., Zamaraeva, J., Sertakova, E., Kistova, A., Semenova, A., Shishatsky, N., Nevzorov, V., Ilbeykina, M., \& Pimenova, N. (2013). Novoe buduschee Sibiri [New Future of Siberia]. Krasnoyarsk: Siberian Federal University. [in Russian]

Kaymaz, I. (2013). Urban Landscapes and Identity. In M. Ozyavuz (Ed.) Advances in Landscape Architecture. InTech.

Kearney, M. (1995). The Local and the Global: The Anthropology of Globalization and Transnationalism. Annual Review of Anthropology, 24, 547-565.

King, A.D. (1999). (Post)colonial geographies: material and symbolic. Historical Geography, 27, 99-118.

Kistova, A., Pimenova, N., Zamaraeva, J., \& Reznikova, K. (2014). Research possibilities for studying the indicators of quality of life of indigenous peoples of the North (based on the study of indigenous peoples of the North of Russia). Life Science Journal, 11(6s).

Knox, P., \& Pinch S. (2009). Urban social geography. An introduction to urban geography. Routledge.

Kolesnik, M., \& Mirkes, M. (2011). Principles of Symmetry in the Krasnoyarsk City Space and Processes of the Regional Identity. Journal of Siberian Federal University. Humanities \& Social Sciences, 12 (4), 1727-1742.

Koptseva, N. P., \& Kirko, V. I. (2014a). Processes of Acculturation Khakases (Indigenous People of Southern Siberia), Living Outside of the Khakassia in the Urban and Student Environment. American Journal of Applied Sciences, 11 (12), 1969-1975.

Koptseva, N. P., \& Kirko, V. I. (2014b). The information basis for formation of positive ethnic identities in the process of acculturation of indigenous peoples of the Arctic Siberia (Krasnoyarsk, Russia). Life Science Journal, 11(8).

Koptseva, N.P., Zamaraeva, Yu. S., \& Kirko, V.I. (2015). Ethnic Migration in Central Siberia (Krasnoyarsk Territory). Mitteilungen Klosterneuburg Journal, 65 (2), 2-20.

Koptseva, N.P., Zamaraeva, Yu. S., \& Sertakova, E.A. (2011). Sociocultural Research of the Cultural Requirements of the Residents of the Krasnoyarsk City. Journal of Siberian Federal University. Humanities \& Social Sciences, 4 (11), 1577-1588.

Lefebvre, H. (1991). The production of space. Oxford: Basil Blackwell.

Libakova, N., Sitnikova, A., Sertakova, E., Kolesnik, M., \& Ilbeykina, M. (2014). Interaction of the Yakut ethnicity and biological systems in the territory of the Sakha Republic (Hordogoy settlement, Suntarsky District) and Krasnoyarsk Krai (Essey settlement, Evenks District). Life Science Journal, 11(6s).

Low, S. (1996). The Anthropology of Cities: Imagining and Theorizing the City. Annual Review of Anthropology, 25, 383-409.

Mitchell, D. (2000). Cultural Geography: A Critical introduction. Wiley-Blackwell.

Mumford, L. (1966). The city in history. Its rigin, its transformation and its prospects. Harmondsworth: Penqun.

Nistarova, A.A. (2013). Region v sisteme globaliziruyuschegosya mira (na primere moskovskogo megapolisa: sotsialno-filosofskiy analiz [Region in the globalizing world (for example, the Moscow metropolis): socio-philosophical analysis]. Moskow. [in Russian]

Petrov, K.G. (2012). Discussions about the Big Krasnoyarsk City Planning Design in 1930. Journal of Siberian Federal University. Humanities \& Social Sciences, 5 (5), 685-690.

Pimenova, N.N. (2011). Wooden Zodchestvo of Krasnoyarsk City as the Space for Forming Territorial and Ethno-Cultural Identity. Journal of Siberian Federal University. Humanities \& Social Sciences, 4 (12), 1784-1793.

Proshansky, H.M. (1978). The city and self-identity. Environment and Behavior, 57-83.

Proskurin, S.A. (2000). Sovremennyi miroporyadok i buduschee Rossii [The modern world order and Russia's Future]. Bezopasnost Evrazii [Security in Eurasia], 2, 325-336. [in Russian]

Sassen, S. (1991). Global city: New-York, London, Tokio. Princeton university.

Sassen, S. (2012). Cities in a world economy. Columbia University.

Semenova, A.A., \& Soshenko, M.V. (2011). Image of Siberia in Artist Aleskander Surikov's Works. Journal of Siberian Federal University. Humanities \& Social Sciences, 4 (12), 1743-1766.

Sertakova, EA (2014). Vizualizatsiya obraza goroda i oblika goroghan v chasovne Paraskevy Pyatnitsy v Krasnoyarske [Visualization image of the city and urban appearance in the chapel of St. Paraskeva in Krasnoyarsk]. Urbanistics, 2, 50-64. [in Russian]

Smith, R.W., \& Bugni V. (2006). Symbolic interaction theory and architecture. Symbolic Interaction, 29(2). [Online] Available: http://digitalscholarship.unlv.edu/sociology_pubs/5 (March 3, 2015).

Soja, E. (1989). Postmodern Geographies: The Reassertion of Space in Critical Social Theory. London, New York: Verso.

Sztompka P.(1993). The Sociology of Social Change. Oxford and Cambridge: Blackwell

Westwood, S., \& Williams, J. (2005). Imagining cities: scripts, signs, memories. Taylor \& Francis e-Library.

Wu, F. (2000). The Global and Local Dimensions of Place-making: Remaking Shanghai as a World City. Urban Studies, 37, $1359-1377$.

Zukin, Sh. (1996). The Cultures of Cities. Wiley-Blackwell. 
